\title{
Uridine Diphosphate Hexoses in Leukocytes and Fibroblasts of Classic Galactosemics and Patients with Other Metabolic Diseases
}

\author{
JAMES B. GIBSON, ROBERT A. REYNOLDS, MICHAEL J. PALMIERI, BEATRICE \\ STATES, GERARD T. BERRY, AND STANTON SEGAL \\ Division of Biochemical Development and Molecular Diseases, Children's Hospital of \\ Philadelphia, and the Department of Pediatrics, University of Pennsylvania School of Medicine, \\ Philadelphia, Pennsylvania 19104
}

\begin{abstract}
ABST content of cells that have more complete metabolic patterns than erythrocytes, which have been commonly used in the study of galactosemia, the concentrations of uridine diphosphate galactose (UDPgalactose) and uridine diphosphate glucose (UDPglucose) were determined in white blood cells (WBC) and fibroblasts cultured from skin biopsies. Leukocyte UDPgalactose and UDPglucose values were determined in 60 normal individuals, 14 classic galactosemics, and 18 patients with other metabolic diseases on protein-restricted and low-lactose diets. There was no difference in the average concentration of these compounds between any of these groups. There was no relationship between age and WBC UDPhexose content or correlation of WBC and erythrocyte UDPhexose levels in the same blood specimens. WBC from galactosemic individuals differ from their red blood cells because the former do not show the low average UDPgalactose levels and abnormal UDPglucose to UDPgalactose ratio previously reported for erythrocytes from galactose-1-phosphate uridyltrans-
\end{abstract}

\section{BSTRACT}

ferase-deficient individuals. Fibroblast cell lines from 10 normal and 10 galactosemic individuals, cultured and grown to confluence in glucose medium, also showed no difference in nucleotide sugar concentrations. Thus far, of the cell types easily available, red blood cells appear to be unique in showing an abnormality in nucleotide sugar metabolism. The fact that galactosemic fibroblasts demonstrate no abnormality in the concentration of these compounds suggests that the defective galactosylation that has been observed in galactosemic fibroblasts is not due to unavailability of UDPgalactose. (Pediatr Res 36: 613-618, 1994)
Abbreviations
TCA, trichloroacetic acid
UDPhexose, uridine diphosphate hexose
UDPgalactose, uridine diphosphate galactose
UDPglucose, uridine diphosphate glucose
WBC, white blood cell

Since Ng et al. (1) reported that UDPgalactose concentration was low in red blood cells, liver biopsies, and cultured fibroblasts of patients with classic galactosemia, much attention has been focused on cellular UDPhexose levels. It has been suggested that a deficiency of UDPgalactose, the obligate donor in galactosylation, could lead to a defect in this important cellular process. The postulate that impaired galactosylation may be the basis for the long-term complications seen in galactosemics,

Received March 25, 1994; accepted June 14, 1994.

Correspondence and reprint requests: James B. Gibson, M.D., Ph.D., Division of Biochemical Development and Molecular Diseases, Children's Hospital of Philadelphia, 34th Street and Civic Center Boulevard, Philadelphia, PA 19104.

Supported by National Institutes of Health Training Grant HD 07107, National Institutes of Health Grant PO1-HD 29847, and a grant-in-aid from the Mead Johnson Nutritional Group. who adhere to prescribed lactose-free diets, has made UDPgalactose a pivotal substance for investigation.

Several reports have recently compared erythrocyte nucleotide sugar levels in normal subjects and galactosemics (1-4). Using HPLC, a direct chemical assay for determination of UDPhexoses, we have found that the average concentration of erythrocyte UDPgalactose in patients with galactosemia is significantly different from that of normal subjects. This difference was significant despite the overlap of many individual values in the two populations $(2,4,4 a)$. A prominent feature of erythrocytes from most patients with galactosemia is the highly abnormal ratio of UDPglucose to UDPgalactose $(2,4,4 a)$.

Historically, erythrocytes have been used for analysis because of their ease of availability and their currency for diagnosis, diet monitoring, and clinical research of galactosemia. The first demonstration of the enzymatic defect 
in classic galactosemia was performed in erythrocytes (5). Subsequently, the diagnosis of this disorder has been routinely made by measuring galactose-1-phosphate uridyltransferase in these cells, and erythrocyte accumulation of galactose-1-phosphate has been used for monitoring dietary therapy (6). Despite their usefulness in this regard, the repertoire of metabolic patterns and responses of the erythrocyte may be limited and may not be representative of the processes occurring in other cell types.

To broaden the scope of our studies of the metabolism of UDPhexoses, we examined nucleotide sugar concentrations in circulating leukocytes and in fibroblasts cultured from skin biopsies of normal individuals and patients with galactosemia. For comparison, leukocytes from patients with other metabolic diseases on proteinrestricted and low-lactose diets were studied. Circulating leukocytes represent an available alternative tissue whose metabolic fluxes may be more representative of other body tissues. They contain the Leloir metabolic pathway involved in the metabolism of galactose. WBC from patients with galactosemia show similar galactose1-phosphate uridyltransferase defects (7) and accumulate galactose-1-phosphate to the same extent as erythrocytes (8). Palmieri et al. (9) have described a method for the accurate determination of nucleotide sugars in normal WBC. This procedure facilitates the examination of leukocytes and cultured fibroblasts from patients with galactosemia.

Fibroblasts are a traditional cell type for biochemical investigation in vitro, representing a renewable and easily manipulated biochemical resource. They are a model that has often been used to study both normal and abnormal galactose metabolism $(7,10-12)$. Galactosemic fibroblasts fail to replicate in galactose-containing medium, mimicking the untreated patient's failure to thrive (12). Fibroblasts are important for assessing nucleotide sugar concentrations because fibroblasts from galactosemic patients, when grown in glucose, show evidence of abnormal galactosylation $(10,11)$. This abnormality was demonstrated by an increased number of vacant galactose acceptor sites on complex glycoconjugates (11).

In this paper, we report that leukocytes from patients with galactosemia, in contrast to the published results in erythrocytes $(2,4)$, do not differ from WBC from normal individuals in their concentrations of UDPgalactose and UDPglucose or the ratio of UDPglucose to UDPgalactose. There is no correlation between the concentrations of UDPhexoses in erythrocytes and leukocytes. Patients with other metabolic diseases whose erythrocytes showed a low average UDPgalactose concentration $(2,4$, 4a) also had normal leukocyte UDPgalactose levels. Fibroblasts from normal individuals and patients with galactosemia also exhibit no difference in UDPgalactose and UDPglucose values. In this regard, our data are in contrast to those of $\mathrm{Ng}$ et al. (1) and suggest that low concentrations of UDPgalactose are not responsible for the defective galactosylation in fibroblasts from patients with galactosemia.

\section{METHODS}

Subjects. The normal population consisted of 60 individuals aged birth to $64 \mathrm{y}$. There were 28 females and 32 males. The individuals with classic galactosemia consisted of 14 patients ranging in age from $21 \mathrm{~d}$ to $28 \mathrm{y}$. There were eight females and six males. Genotype information was known for 12 galactosemics, with six being homozygous for the Q188R mutation (13), five having a single copy of the Q188R mutation, and one not having a Q188R mutation. Eighteen subjects with other metabolic disorders, whose therapy requires a low-protein diet and consequently a low-lactose diet, were also studied. They ranged in age from 1.3 to $22 \mathrm{y}$ and consisted of 13 males and five females. Informed consent for venipuncture was obtained from either the donors or their guardians in accord with study approval by the Children's Hospital of Philadelphia Institutional Review Board.

Blood specimen preparation. Leukocytes were isolated by the method of Skoog and Beck (14) from 6 to $8 \mathrm{~mL}$ of blood and prepared for HPLC by the method described by Palmieri et al. (9). Erythrocytes were prepared as previously described (15) from additional blood obtained at the same time from all galactosemics and patients with other metabolic disorders and from 56 of the normal subjects so that UDPhexose content could be compared between leukocytes and erythrocytes.

Growth and preparation of fibroblasts. Skin biopsies were performed by a punch technique after informed consent. Fibroblast lines were initiated for all 10 normal individuals and for three classic galactosemics. Seven other galactosemic skin fibroblast lines were obtained from the National Institute of General Medical Sciences Human Genetic Mutant Cell Repository, Camden, NJ. All lines from galactosemic individuals were shown to be deficient in galactose-1-phosphate uridyltransferase. Genotypes were known or determined for nine lines; three were homozygous Q188R/Q188R, two had Q188R in a single copy, and four lines did not have Q188R mutations.

Cell lines were maintained in minimal Eagle's medium supplemented with $2 \mathrm{mM}$ glutamine and $20 \% \mathrm{FCS}$ in 25 $\mathrm{cm}^{2}$ flasks at $37^{\circ} \mathrm{C}$ in a $5 \% \mathrm{CO}_{2} / 95 \%$ air atmosphere. Cells became confluent in 5-7 d and were passed in a 1:2 split by washing the cell layer with $4 \mathrm{~mL}$ of Puck's solution B-EDTA followed by trypsinization with $2 \mathrm{~mL}$ of Puck's solution B-EDTA containing $0.04 \%$ (wt/vol) trypsin. One $\mathrm{mL}$ of this cell suspension was transferred to each new flask, which contained $4 \mathrm{~mL}$ of the medium described above.

Cell harvest. Fibroblasts were harvested at cellular confluence as judged by inspection with phase microscopy. Two to four flasks were used for each analysis. The medium was removed by aspiration, and the cell layer of each flask was washed with $4 \mathrm{~mL}$ of Puck's solution B-EDTA. Cells were removed from the flask by trypsin treatment as described for cell passage. Each flask was rinsed with $2 \mathrm{~mL}$ of PBS without calcium or magnesium, 
$\mathrm{pH}$ 7.4. The rinse solution was added to the trypsin fraction. The cell suspension was centrifuged at $800 \times g$ for $5 \mathrm{~min}$ at $4^{\circ} \mathrm{C}$ in a refrigerated centrifuge. The supernatant was removed by aspiration, the pellet was resus-

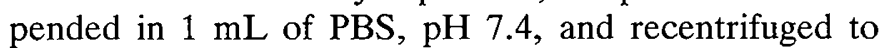
wash the cells. After three additional washes, the pellet was suspended in $1 \mathrm{~mL}$ of ice-cold deionized water and sonicated in a Branson Power Sonifier for $5 \mathrm{~s}$ at a power setting of 5 . The cellular protein was precipitated by the addition of $70 \mu \mathrm{L}$ of $100 \%$ TCA, then placed on ice for 15 $\mathrm{min}$. The TCA removal and subsequent steps were performed as previously described for leukocytes (9).

The protein pellet was dissolved in $100 \mu \mathrm{L}$ of $1.0 \mathrm{~N}$ $\mathrm{NaOH}$, diluted 10-fold, and analyzed for protein according to the method of Lowry et al. (16).

Analytic procedures. UDPgalactose, UDPglucose, and TCA were obtained from Sigma Chemical Co. (St. Louis, $\mathrm{MO})$. The purity and concentration of the UDPgalactose and UDPglucose were confirmed by spectrophotometric analysis. Other reagents for the HPLC were of the highest commercially available purity.

HPLC was performed on $20 \mu \mathrm{L}$ of each sample with a Dionex CarboPac PA-1 anion exchange column (Dionex Corporation, Sunnyvale, CA) on the system described by Palmieri et al. (15) (first half of samples) or with the modifications outlined by Gibson et al. (17).

A series of external chromatographic standards was used to calculate the concentrations of UDPgalactose and UDPglucose. Standard curves for linearity of response and recovery were done with the commercially obtained compounds, taking into account the purity, water of hydration, counterions, and other solvents of each lot.

$\mathrm{Hb}$ determinations were performed on the packed erythrocytes using the commercially available kit (625-A) from Sigma Chemical Co.

All of the values are expressed as $\mu \mathrm{mol}$ of UDPhexose per $100 \mathrm{~g}$ of protein or per $100 \mathrm{~g}$ of $\mathrm{Hb}$. Statistical testing was done with $t$ test with a minimal level of significance of $p=0.05$.

\section{RESULTS}

\section{Leukocyte Sugar Nucleotides}

Effect of age. Palmieri et al. (9) reported that in a group of 33 normal subjects there appeared to be no effect of the donor's age on leukocyte UDPgalactose or UDPglucose in contrast to age-related changes in erythrocytes (2). We have been able to verify that leukocyte UDPhexose con- tent is not related to the donor's age by stratifying the results from 60 normal individuals by subjects' age in 5to $10-y$ groupings up to age 25 and beyond. These results are shown in Table 1. There are few or no differences in the average UDPglucose or UDPgalactose values of the various groups. No age group's results differ from the average values of the whole studied population. In a group of young adults, $28 \pm 5 \mathrm{y}$ old, Borzi et al. (18), using a different HPLC technique, found total leukocyte UDPhexose levels similar to ours. These data led us to examine the values for 14 galactosemics and 18 patients with other disorders of various ages without regard to age.

Comparison of leukocyte UDPhexose concentrations in normal subjects, galactosemics, and patients with other disorders. Figure 1 presents the data for UDPgalactose and UDPglucose in leukocytes of normal subjects and galactosemics. It is readily apparent that there is complete overlap of values for these compounds as well as for their ratios. Table 2 shows that the leukocyte UDPgalactose concentration in galactosemics of $13.41 \pm 6.45$ (mean \pm $\mathrm{SD}) \mu \mathrm{mol} / 100 \mathrm{~g}$ protein does not differ significantly from the $12.42 \pm 4.84$ value found in the normal population. The same conclusion is reached for UDPglucose and total UDPhexose. The ratio of UDPglucose to UDPgalactose in leukocytes is essentially the same in the two groups. Table 2 also shows that the mean leukocyte UDPgalactose concentration of patients with other metabolic disorders, $12.22 \pm 4.97 \mu \mathrm{mol} / 100 \mathrm{~g}$ protein, is indistinguishable from the means of the other two groups. The individual leukocyte UDPgalactose values in this group of patients ranged from 4.8 to $24.6 \mu \mathrm{mol} / 100 \mathrm{~g}$ protein, which is comparable to those shown in Figure 1 for normal subjects or galactosemics. UDPglucose concentrations, total UDPhexose values, and the ratio of UDPglucose to UDPgalactose in leukocytes of the patients with other disorders did not differ from those of the normal population.

Leukocyte versus erythrocyte sugar nucleotide concentrations. The relationship of UDPgalactose content of leukocytes to that of erythrocytes isolated from the same blood specimen is shown in Figure $2 a$. The data show there is no significant correlation between leukocyte and erythrocyte UDPgalactose values for any of the studied populations. Additionally, no correlation existed between values for the two cell types for either UDPglucose concentration (Fig. $2 b$ ) or ratio (data not shown) in any studied population.

Table 1. UDPhexoses in leukocytes of normal subjects by age*

\begin{tabular}{|c|c|c|c|c|c|}
\hline $\begin{array}{l}\text { Age } \\
(y)\end{array}$ & $n$ & $\begin{array}{c}\text { UDPgalactose } \\
(\mu \mathrm{mol} / 100 \mathrm{~g} \text { protein })\end{array}$ & $\begin{array}{c}\text { UDPglucose } \\
\text { ( } \mu \mathrm{mol} / 100 \mathrm{~g} \text { protein })\end{array}$ & $\begin{array}{l}\text { Total UDPhexose } \\
(\mu \mathrm{mol} / 100 \mathrm{~g} \text { protein })\end{array}$ & Ratio UDPG/UDPGal \\
\hline$<5$ & 12 & $12.28 \pm 4.25$ & $34.35 \pm 10.29$ & $46.63 \pm 11.4$ & $3.13 \pm 1.35$ \\
\hline $5-10$ & 6 & $15.00 \pm 5.67$ & $34.55 \pm 8.17$ & $49.51 \pm 11.1$ & $2.49 \pm 0.60$ \\
\hline $10-15$ & 10 & $11.82 \pm 4.09$ & $33.66 \pm 6.12$ & $45.48 \pm 9.46$ & $3.11 \pm 1.00$ \\
\hline $15-25$ & 12 & $12.88 \pm 3.46$ & $36.90 \pm 10.82$ & $49.78 \pm 12.9$ & $3.00 \pm 0.95$ \\
\hline$>25$ & 20 & $12.02 \pm 5.61$ & $28.75 \pm 9.54$ & $40.77 \pm 14.1$ & $2.65 \pm 0.82$ \\
\hline
\end{tabular}

\footnotetext{
* Values are mean $\pm \mathrm{SD}$.
} 


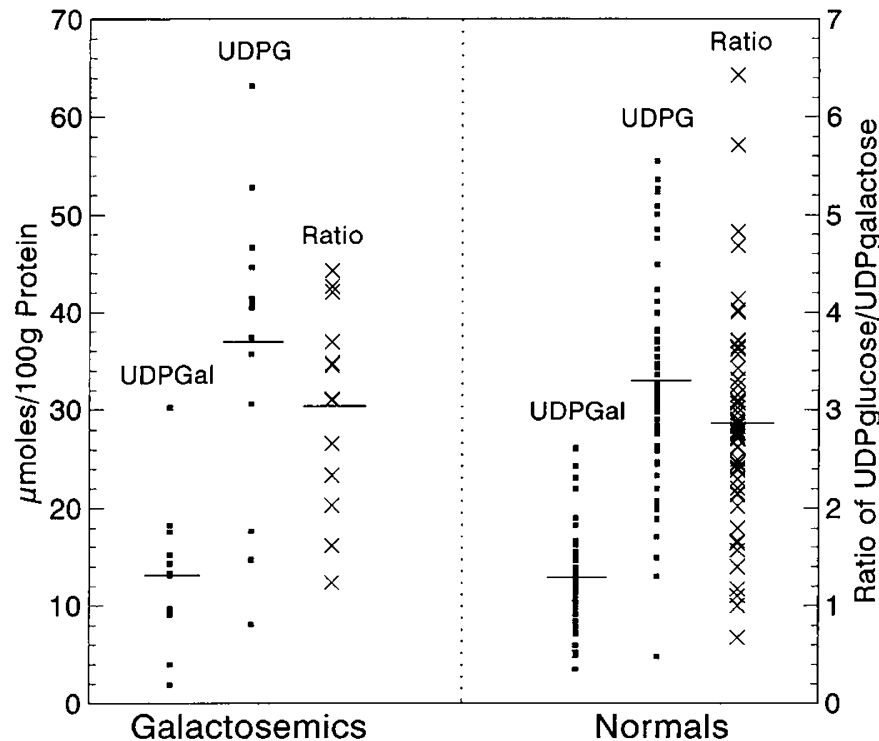

Figure 1. Uridine nucleotide sugar levels in galactosemic and normal leukocytes. UDPG, UDPglucose; UDPGal, UDPgalactose.

\section{Nucleotide Sugar Concentrations in Cultured Fibroblasts}

The levels of UDPgalactose and UDPglucose were determined in 10 normal and 10 galactosemic cell lines grown to confluence. Six of the 10 in each group were analyzed from four to nine times between the fourth and 10th passage, with the average of the determinations taken as the best estimate of the individual cell line values. Figure 3 shows the array of levels in the individual cell lines and indicates no difference in the distribution of the UDPhexose concentrations or the ratio of UDPglucose to UDPgalactose between normal and galactosemic fibroblasts. Table 2 shows the average UDPgalactose level of $42.0 \pm 18.5 \mu \mathrm{mol} / 100 \mathrm{~g}$ protein (mean \pm $\mathrm{SD})$ in normal subjects was similar to the $39.7 \pm 13.8$ value determined in galactosemic cells $(p>0.05)$. Similarly, there was no statistical difference in the mean UDPglucose content, total UDPhexose value, or ratio of UDPglucose to UDPgalactose between these two groups of cell lines.

\section{DISCUSSION}

In contrast to the findings in erythrocytes of galactosemic patients that the average UDPgalactose level is lower than normal and the mean ratio of UDPglucose to
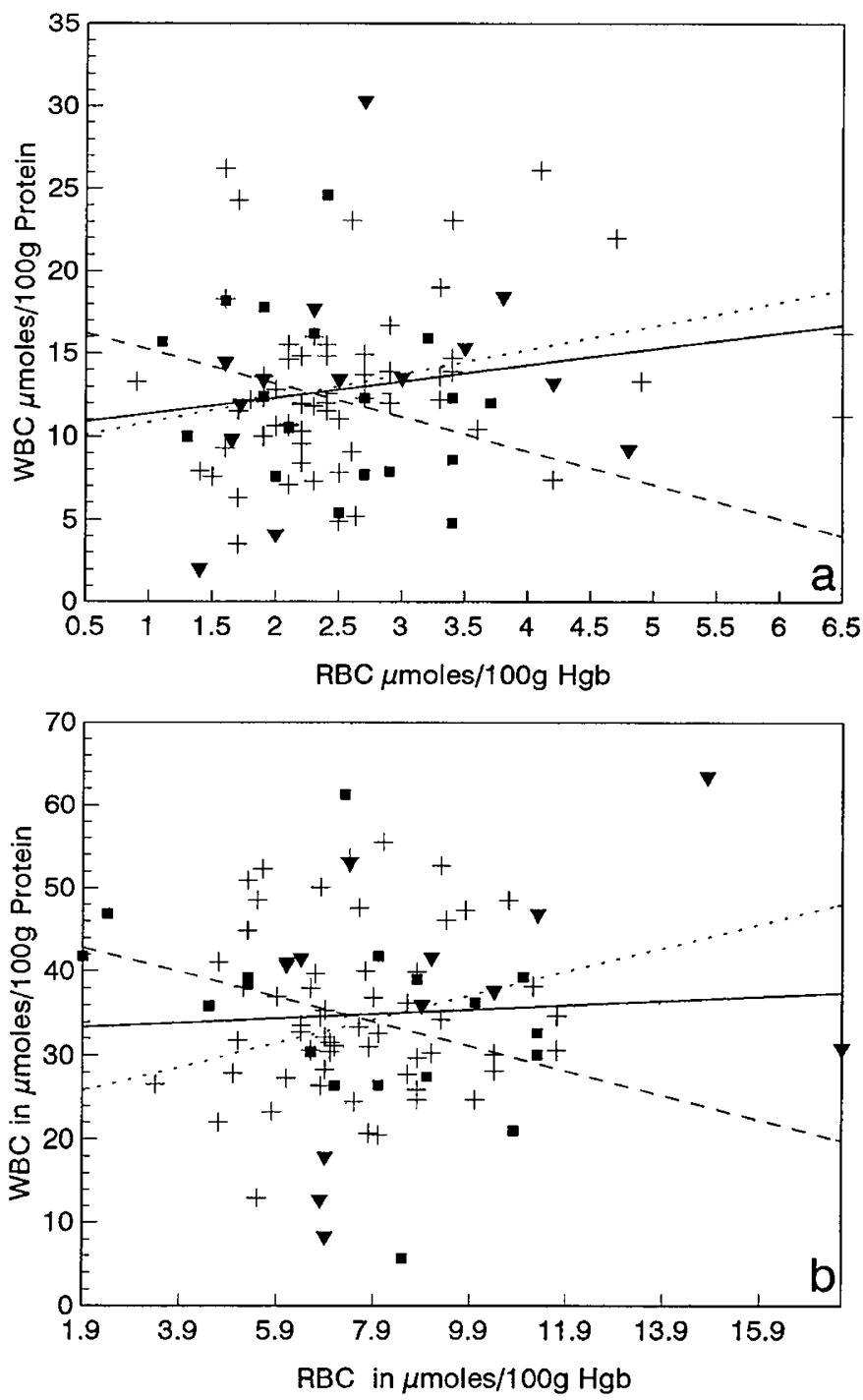

Figure 2. Relationship of UDPhexose levels between leukocytes and erythrocytes in normal subjects, galactosemics, and patients with other metabolic disorders. $R B C$, red blood cells; $H g b$, hemoglobin. $a$, UDPgalactose. The solid line is the regression curve for normal subjects: $\mathrm{y}=10.37+$ $0.98 \mathrm{x}, r=0.21$. The dotted line is the regression curve for galactosemics: $\mathrm{y}$ $=7.37+1.45 \mathrm{x}, r=0.24$. The broken line represents the regression $\mathrm{y}=$ $17.23-2.03 \mathrm{x}, r=-0.30$, for patients with other metabolic diseases. $b$, UDPglucose. The regression curves are $\mathrm{y}=32.9+0.26 \mathrm{x}, r=0.05 ; \mathrm{y}=23.1$ $+1.42 \mathrm{x}, r=0.33$; and $\mathrm{y}=45.6-1.46 \mathrm{x}, r=0.36$, respectively, for normal subjects, galactosemics, and other patients. $+=$ normal subjects; $\boldsymbol{\nabla}=$ galactosemics; $\mathbf{\square}=$ patients with other metabolic disorders.

UDPgalactose is higher than normal $(2,4,4 a)$, our data indicate that there is no abnormality in these parameters

Table 2. UDPhexoses in leukocytes and fibroblasts of normal subjects, galactosemics, and patients with other metabolic diseases*

\begin{tabular}{lccccc}
\hline & $n$ & $\begin{array}{c}\text { UDPgalactose } \\
(\mu \mathrm{mol} / 100 \mathrm{~g} \text { protein })\end{array}$ & $\begin{array}{c}\text { UDPglucose } \\
(\mu \mathrm{mol} / 100 \mathrm{~g} \text { protein })\end{array}$ & $\begin{array}{c}\text { Total UDPhexose } \\
(\mu \mathrm{mol} / 100 \mathrm{~g} \text { protein })\end{array}$ & $\begin{array}{c}\text { Ratio } \\
\text { UDPG/UDPGal }\end{array}$ \\
\hline WBC & & & & & \\
$\quad$ Normal subjects & 60 & $12.42 \pm 4.84$ & $32.44 \pm 10.49$ & $44.86 \pm 13.5$ & $2.84 \pm 1.04$ \\
$\quad$ Galactosemics & 14 & $13.41 \pm 6.45$ & $36.81 \pm 14.3$ & $50.23 \pm 18.8$ & $3.05 \pm 0.95$ \\
$\quad$ Other metabolic diseases & 18 & $12.22 \pm 4.97$ & $34.46 \pm 11.29$ & $46.67 \pm 15.65$ & $2.97 \pm 0.84$ \\
$\quad$ Fibroblasts & & & & & \\
$\quad$ Normal subjects & 10 & $42.0 \pm 18.5$ & $131.4 \pm 54.1$ & $181.5 \pm 72.3$ & $3.39 \pm 1.06$ \\
$\quad$ Galactosemics & 10 & $39.7 \pm 13.8$ & $130.1 \pm 47.5$ & $169.5 \pm 59.2$ & $3.43 \pm 0.81$ \\
\hline
\end{tabular}

*Values are mean \pm SD. 


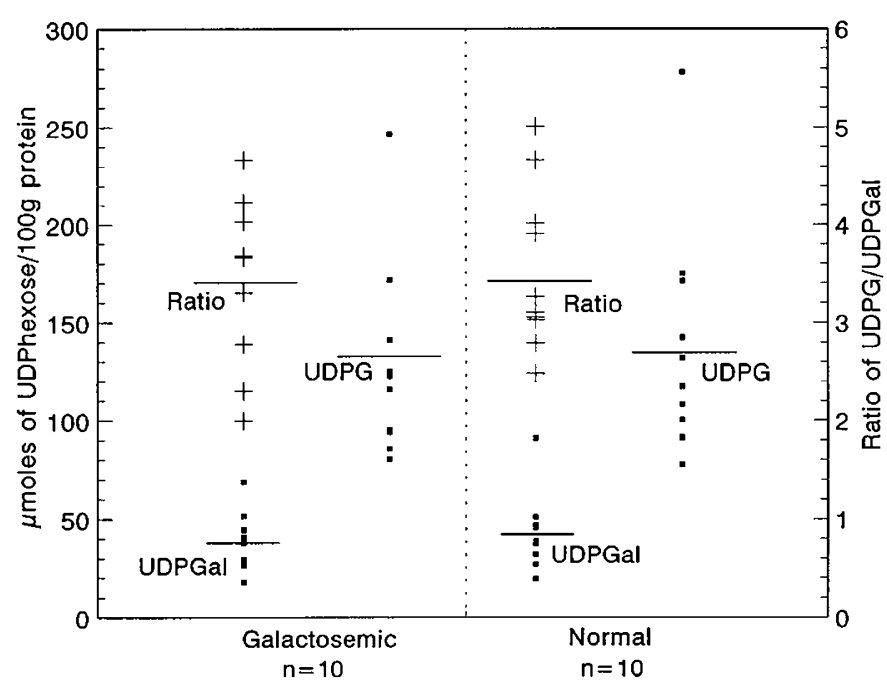

Figure 3. Uridine nucleotide sugar levels in galactosemic and normal fibroblasts. The mean values for each of the six galactosemic and normal cell lines that were assayed repeatedly are plotted along with the single determinations of the other lines. UDPG, UDPglucose; UDPGal, UDPgalactose.

in leukocytes or cultured fibroblasts. Additionally, no abnormality in UDPhexose level exists in the leukocytes of patients with other metabolic disorders, unlike the findings in their erythrocytes $(2,4 \mathrm{a})$. The lack of correlation between erythrocyte and leukocyte sugar nucleotide levels from the same blood specimen in normal subjects, galactosemic patients, and patients with other metabolic disorders strengthens the conclusion that the metabolic regulation of UDPhexose levels differs in these blood elements. The difference also appears when age is examined as a factor. Red blood cells from both normal and galactosemic children under age $10 \mathrm{y}$ have higher levels of UDPhexoses than older individuals $(4,4 \mathrm{a})$, whereas WBC show no such age dependence.

Leukocytes, although containing the Leloir metabolic pathway of galactose metabolism (7) and having a more complete metabolic complement than erythrocytes, have not been used to the same extent as erythrocytes in galactosemia investigations. Erythrocytes are easily obtained, whereas leukocytes have to be isolated and manipulated in a more complicated fashion. However, the examination of leukocyte galactose metabolism in galactosemics may give a more accurate assessment of the defect than can be obtained in erythrocytes. Long-term lymphoid cell lines have been used in galactosemic studies (19). In this regard, our own findings that leukocyte sugar nucleotide content is not different in granulocytes or lymphocytes (9) suggest that immortalized lymphocytes may be a suitable model for study of UDPhexose metabolism.

Numerous studies have been made to assess the metabolism of galactose by cultured galactosemic fibroblasts $(7,8,10-12)$. They grow poorly and die when cultured in galactose-containing medium but show normal growth on glucose or inosine, although there is accumulation of galactose-1-phosphate and galactitol (20).
Despite these abnormalities, our findings show that, when grown to confluence in glucose-containing medium, galactosemic fibroblasts have normal UDPgalactose content and a normal UDPglucose to UDPgalactose ratio. It is interesting to note that there is a 3-fold difference in UDPhexose content between normal as well as galactosemic leukocytes and fibroblasts, which may be related to the type-specific metabolic requirements of these cells.

Our results on the levels in fibroblasts are at variance with those of $\mathrm{Ng}$ et al. (1), who reported that in six galactosemic cell lines there was a marked lowering of UDPgalactose content compared with four normal cell lines. Although different growth conditions and the degree of confluence may contribute to the difference, it may be more related to $\mathrm{Ng}$ et al. using an inaccurate enzymatic method to assay for UDPgalactose and UDPglucose as we have demonstrated in erythrocytes (17).

The mechanism for maintaining the steady state level of cellular UDPgalactose and UDPglucose is complex and not totally understood. If galactose is being metabolized via the Leloir pathway, UDPgalactose is formed from galactose-1-phosphate via the action of galactose-1phosphate uridyltransferase. In the absence of this reaction in classic galactosemia, $\mathrm{Ng}$ et al. postulated cellular UDPgalactose would be low (1). UDPglucose is readily formed from uridine triphosphate and glucose-1phosphate by the action of UDPglucose pyrophosphorylase. In contrast, the formation of UDPgalactose from galactose-1-phosphate via UDPgalactose pyrophosphorylase is minimal (21). On the other hand, UDPgalactose is readily formed from UDPglucose via UDPgalactose-4epimerase. This enzyme normally maintains an equilibrium between the two UDPhexoses with the ratio of UDPglucose to UDPgalactose being approximately 3 to 1 $(22,23)$. This is the average ratio of the uridine sugar previously observed in normal erythrocytes $(2,4,4 a)$ and now reported in normal leukocytes and fibroblasts. The fact that erythrocytes from many galactosemic patients have abnormally high ratios of UDPglucose to UDPgalactose $(2,4,4 a)$ suggests that the bidirectional flux of UDPhexoses catalyzed by the epimerase is perturbed in the steady state milieu of the galactosemic erythrocyte. Leukocytes and cultured fibroblasts from galactosemics have a normal ratio of UDPglucose to UDPgalactose, which indicates such a dysequilibrium in the epimerization of UDPhexoses is not a common feature of all galactosemic tissues. Whether such a dysfunction exists in target organs to explain long-term complications of galactosemia involving the brain and ovary is not yet known (24), but it seems unlikely. $\mathrm{Ng}$ et al. (1) reported low UDPgalactose in several long-frozen liver biopsies from galactosemics, which raises this possibility. This observation needs further exploration and assessment by more appropriate HPLC analysis of target organ specimens.

Evidence exists that there is defective galactosylation of cell glycoconjugates in galactosemia. Haberland et al. (25) described an abnormal glycoprotein pattern in the 
brain of a galactosemic patient. More recently, Dobbie et al. (10) reported an abnormal ratio of galactose to mannose in galactosemic fibroblasts, and Ornstein et al. (11) reported an increased number of vacant galactoseaccepting sites in galactosemic fibroblasts. The fact that we demonstrate UDPgalactose levels to be normal in galactosemic fibroblasts suggests that defective galactosylation observed in these cultured cells is not due to the unavailability of UDPgalactose. Other etiologies, such as an intrinsic defect in UDPgalactose transfer to acceptor molecules, must be explored.

Acknowledgment. The authors thank Drs. Louis J. Elsas II and Judith Fridovich-Kiel for performing mutational analysis on leukocytes and fibroblast lines and Dorothy Harris for technical assistance.

\section{REFERENCES}

1. Ng WG, Xy YK, Kaufman FR, Donnell GN 1989 Deficit of uridine diphosphate galactose in galactosemia. J Inherit Metab Dis 12:257-266

2. Berry GT, Palmieri MJ, Heales S, Leonard JV, Segal S 1992 Red blood cell uridine sugar nucleotide levels in patients with classic galactosemia and other metabolic disorders. Metabolism 41:783-787

3. Kirkman HN 1990 Uridine diphosphate glucose and uridine diphosphate galactose in galactosemia. J Pediatr 117:838-839

4. Keevill NJ, Holton JB, Allen JT 1993 The investigation of UDPglucose and UDPgalactose concentration in red blood cells of patients with classical galactosaemia. Clin Chem Acta 221:135-142

4a.Gibson JB, Reynolds RA, Palmieri MJ, Berry GT, Elsas LJ, Levy HL, Segal S 1994 Comparison of erythrocyte uridine sugar nucleotide levels in normals, classic galactosemics and patients with other metabolic disorders. Metabolism (in press)

5. Isselbacher KJ, Anderson EP, Kurahashu K, Kalchar HM 1956 Congenital galactosemia a single enzymatic block in galactose metabolism. Science 123:635-636

6. Donnell GN, Bergren WR, Perry G, Koch R 1963 Galactose-1-phosphate in galactosemia. Pediatrics 31:801-810

7. Tedesco TA, Mellman WJ 1969 Galactose-1-phosphate uridyltransferase and galactokinase activity in cultured human diploid fibroblasts and peripheral blood leukocytes. I. Analysis of transferase genotypes by the ratio of the activities of the two enzymes. J Clin Invest 48:2390-2397

8. Weinberg KA, Segal S 1960 Effect of galactose-1-phosphate on glucose oxidation by normal and galactosemic leukocytes. Science 132:1015-1016
9. Palmieri MJ, Reynolds RA, Gibson JB, Berry GT, Segal S 1993 Concentration of white blood cell UDPgalactose and UDPglucose determined by high performance liquid chromatography. Enzyme Protein 47:105-115

10. Dobbie JA, Holton JB, Clamp JR 1990 Defective galactosylation of proteins in cultured skin fibroblasts from galactosemic patients. Ann Clin Biochem 27:274-275

11. Ornstein KS, McGuire EJ, Berry GT, Roth S, Segal S 1992 Abnormal galactosylation of complex carbohydrates in cultured fibroblasts from patients with galactose-1-phosphate uridyltransferase deficiency. Pediatr Res 31:508511

12. Miller LR, Gordon GB, Bensch KG 1968 Cytologic alterations in hereditary metabolic disorders. 1. The effect of galactose on galactosemia fibroblasts in vitro. Lab Invest 19:428-436

13. Leslie ND, Immerman EB, Flach JE, Florez M, Fridovich-Keil JL, Elsas LJ 1992 The human galactose-1-phosphate uridyltransferase gene. Genomics 14:474-480

14. Skoog WA, Beck WS 1956 Studies on the fibrinogen, dextran and phytohemagglutinin methods of isolating leukocytes. Blood 11:436-456

15. Palmieri MJ, Berry GT, Player DA, Rogers S, Segal S 1991 The concentration of red blood cell UDPglucose and UDPgalactose determined by highperformance liquid chromatography. Anal Biochem 194:388-393

16. Lowry OH, Rosebrough NJ, Farr AL, Randall RJ 1951 Protein measurement with Folin phenol reagent. J Biol Chem 193:265-275

17. Gibson JB, Reynolds RA, Rogers S, Palmieri MJ, Segal S 1993 Uridine diphosphoglucose content of human erythrocytes: assessment by conversion to uridine diphosphoglucuronate. J Pediatr 123:906-914

18. Borzi RM, DalMonte P, Uquccioni M, Meliconi R, Facchini A 1992 Intracellular nucleotides of lymphocytes and granulocytes from normal aging subjects. Mech Aging Develop 64:1-11

19. Beratis NG, Wilbur L 1987 Galactose metabolism in transferase deficient galactosemic and normal long-term lymphoid cell lines. J Inherit Metab Dis 10:347-358

20. Schaub J, Shin-Boehring Y, Wiese B, Rabin P, Haas P 1979 Metabolism of galactose and accumulation of galactose-1-phosphate in various cell types of cultured fibroblasts for galactosemia. In: Hommes FA (ed) Models for the Study of Inborn Errors of Metabolism. Elsevier/North Holland Biomedical Press, Amsterdam, pp 319-327

21. Shin YS, Neidermeier H-P, Endres W, Schaub J, Weidinger S 1987 Agarose gel isoelectrofocusing of UDPgalactose pyrophosphorylase and galactose-1phosphate uridyltransferase. Development aspect of UDPgalactose pyrophosphorylase. Clin Chim Acta 166:27-35

22. Maxwell ES 1957 The enzymic interconversion of uridine diphosphogalactose and uridine diphosphoglucose. J Biol Chem 229:139-151

23. Tsai CM, Holmberg N, Ebner KE 1970 Purification, stabilization and properties of bovine mammary UDPgalactose-4-epimerase. Arch Biochem Biophys 136:233-244

24. Waggoner DD, Buist NRM, Donnell GN 1990 Long-term prognosis in galactosaemia: results of a survey of 350 cases. J Inherit Metab Dis 13:802-818

25. Haberland C, Perou M, Brunngraber EG 1971 The neuropathology of galactosemia: a histopathological and biochemical study. J Neuropathol Exp Neurol 30:431-437 